\title{
Brazil And Argentina: Hegemonic Crises, Wasted Decade And Challenges Of Latin American Post-Neoliberalism In The Capi- talism Of Knowledge
}

\author{
https://doi.org/10.21272/sec.4(2).44-59.2018
}

\section{José Benjamín Lujano López}

PhD Candidate, Professor of Economic Development, Faculty of Economics, National Autonomous University of Mexico, Mexico

\section{Carlos Manuel Sánchez Ramírez}

PhD Candidate, Institute of Economic Research, National Autonomous University of Mexico, Member of the Globalization, Knowledge and Development Program of Institute of Economic Research of the National Autonomous University of Mexico, Mexico

\begin{abstract}
This article exposes the main arguments about the explanation of persistent economic backwardness and a decade wasted in Latin America, through the study of two national experiences, namely: Brazil and Argentina. In this sense, it is pointed out that due to the failure of the Import Substitution model and the global institutional change that led to the liberalization of national economies, in Latin American countries a series of politicoeconomic reforms called neoliberals are applied in the decade of 1980, but this economic model generated a regression in the main economic and social indicators of the region.

The so-called neo-development arises, as a political-economic movement that sought to establish an alternative to the neoliberal model. The previous process was promoted by Lula da Silva in Brazil and Néstor Kirchner and Cristina Fernández in Argentina. But, the neo-development failed as a hegemonic project, generating a return to governments attached to the more conservative bourgeois factions (exporting landowners and agrominers), exemplified in the coup d'état against Dilma Rousseff in Brazil and the triumph of Mauricio Macri in Argentina, situations that highlighted the unresolved hegemonic crisis within the historical blocs of the countries. In this context, within the framework of a new Development Phase or Knowledge Capitalism, this possibility of an economic - structural transformation of the Latin American economies has been held back (Ramírez and Sztulwark, 2018), thus constituting a wasted decade for development in our region. The main objective is to show the validity and explanatory capacity of the theoretical contribution of Antonio Gramsci, to unravel the challenges and opportunities of the world historical change in Brazil and Argentina, through a long term historical analysis of both Nations.

The investigation is presented in the following logical sequence. In sub-section 1, the main conceptual elements developed by Antonio Gramsci, interpretative axes of the historical process of social development. Next, in subsection 2 the historical and empirical analysis of the Brazilian economy will be developed, and in the subsection 3 the study of the Argentine economy will be studied.
\end{abstract}

Keywords: hegemonic crisis, wasted decade, neodevelopment.

JEL Classification: O10, O54, P52.

Cite as: López, J. B. L., Ramírez, C. M. S. (2018 Brazil And Argentina: Hegemonic Crises, Wasted Decade And Challenges Of Latin American Post-Neoliberalism In The Capitalism Of Knowledge. SocioEconomic Challenges, 4(2), 44-59. https://doi.org/10.21272/sec.4(2).44-59.2018.

(C) The Authors, 2018. This article is published with open access at Sumy State University.

\section{Introduction}

Rarely in history do nations have the objective conditions to break the links of the chains that bind them to underdevelopment. The dawn of the 21st century was one of those few historical exceptions for Latin America, but these conditions were not taken advantage of. The social energy mobilized against neoliberalism, with the political turn towards progressive governments, as well as the torrent of wealth that flowed to our region through agro - mining exports, did not materialize in a long-lasting socio structural change. The current rise of 
conservative political forces to national governments means the closure of the progressive cycle and the announcement that the first decade of this new century meant a wasted decade for the subcontinent.

Derived from neoliberal economic policies inspired by the Washington Consensus and applied in much of Latin America in the last quarter of the twentieth century, the living conditions of the population worsened and, after a series of economic crises, the correlation of forces within of the historical corporate blocks changed at the beginning of the 21st century. The reshuffling of forces led governments to implement alternative development paths to neoliberalism, although, finally, the problems of relative economic backwardness were not solved and no structural change was generated in their economies under the conditions of the new Development Phase or Knowledge Capitalism, which has returned to a political orthodoxy in the middle of the second decade of the new century. Due to its specific weight in the Latin American region and its clear fluctuations in state action, the cases of Brazil and Argentina are particularly important.

The hypothesis that arises is that the last explanation of the new rise of the conservative political forces associated with neoliberalism is not a conjunctural event, but the product of the prolonged hegemonic crisis that the analyzed countries have been dragging within their historical blocks from at least the twentieth century. Characterized in its essence by the existence of bourgeois fractions with a weak ability to summon the rest of the social forces around projects of national character, which make possible the unity within the dominant fractions and with respect to the subaltern classes, the crisis of the hegemonic function, in the gramscian sense, explains the constant political change in the region.

In this context of inter-bourgeois dispute and antagonistic tensions, neo-development emerged, which was presented as an alternative path to neoliberalism, having a strong impact on some intellectual sectors, political forces and acting governments, especially in countries such as Brazil and Argentina. But the balance of that bet is already known: the neo-development project embodied in the governments of the Labor Party in Brazil and the Peronist Party in Argentina has been liquidated by the recent arrival of conservative political forces. The coup d'état against Dilma Rousseff in Brazil, as well as the triumph of Mauricio Macri in Argentina, has given the final blow to this project.

The analysis presented below, addresses the rise and crisis in the actions of the State during the import substitution model (ISI) in these two countries and the insertion of each to neoliberalism under conditions of crisis of hegemony within their respective historical blocks, to move to the implementation of the neo-development and its exhaustion derived from the prevailing unresolved crisis of the hegemonic function, which configures a wasted decade, as well as a new withdrawal of the actions of the State before the return of liberalism and economic orthodoxy.

In a brief and concise manner, we will present the main theoretical elements raised by Gramsci, on which the research and analysis is based. Although for reasons of space we will not develop the above in a broad way, the reader will be able to grasp the formulations indicated in the exposition of the case studies, where the theory appears diluted throughout the text fulfilling its primary function: to explain the concrete reality. The Gramscian theory will allow us to understand the contemporary historical change in the national historical experiences, advancing in the overcoming of a limited understanding of the development, to orientate towards the incorporation of the social groups under the concept of hegemony, articulating its actions in the structural field with the socio-spatial and ideological-institutional spectrum, corresponding to the dynamics of the superstructural sphere.

\section{As a theoretical framework}

Antonio Gramsci stressed that politics is an autonomous area of society within historical limits, built by the material structure of capitalism, in which a group of the bourgeoisie is imposed through the action and conscious organization embodied in a specific state formation.

In Marxist historical materialism, the state is a social construction that results from the division of society into social classes to guarantee the viability of the social division of capitalist labor; the State expresses itself as the hegemony of a bourgeois group that directs society not only through coercion, but also through non-coercive apparatuses of hegemony. To understand the above, Gramsci proposed a series of theoretical lenses around the concept of hegemony necessary to analyze the socio-economic and techno-economic relations that intervene between the main groups of the dominant classes and the classes subject to their sphere of influence. 
Based on the foregoing, he stated that when a new Development Phase of capitalism is materialized, structural changes are made that imply the expansion of new forms of relationship between civil society and political society based on consensus ${ }^{16}$, and correspond to an organic transformation of state superstructural training in an enlarged or full state, which transcends the coercive scope of the ruling elites ${ }^{17}$ and extends its hegemonic capacity by attracting the sphere of influence of the activity of organizations, institutions and civil society actors from the exercise of consensus. Under this logic, the concept of an expanded State ${ }^{18}$ encompasses both dimensions of the State, as a political society and as a civil society; it is the State as a condensation of political relations, it is not only the area where coercion is concentrated, but also the scope of the exercise of consensus.

Among the tasks for the creation of favorable conditions for the maximum expansion of the dominant group, is the extension of the State's instruments to fulfill its economic function of adapting the subaltern classes to the economic production apparatus (Buci-Glucksmann, 1979: 122), a situation that marks the importance of establishing an additional conceptual element that organically links the economic structure with the superstructural complex, so the dilemma of organically linking the structural economic framework with the class society - State relations is synthesized by Gramsci in the concept of Historic Block (HB), as a set of political, ideological and cultural praxis that must be functional to the structure in accordance with prevailing socioeconomic conditions (Portelli, 1977: 48-49). This concept goes beyond a simple class alliance, since it involves the complex development of superstructures, the realization of an expanded State ${ }^{19}$.

The concept of HB is fundamental in the gramscian theoretical framework to assess the degree of development of a given State. In general terms, in the developed countries there is a HB with a strong hegemonic function, with a relatively greater degree of development of civil society as a sphere of predominance of consensus, in contrast to political society as a sphere of predominance of coercion, that corresponds to a State in its broad meaning; In contrast, in the backward countries, a HB with a weak hegemonic function usually occurs, with a relatively lesser degree of development of civil society as a sphere of consensus prevalence, compared to political society as a sphere of predominance of coercion. corresponds to a State in a restricted sense.

That State in a restricted sense shows the inability of the ruling classes to summon the rest of the social classes around an industrialization or development project based on a certain phase of capitalism; the lack of this call to agree to the rest of the classes around a development project with a specific economic base, lays the foundations of a crisis of hegemony. In this sense, the hegemonic group will follow the logic of development of backward productive structures, since the country's development project will not follow the industrial pattern of the current Development Phase but predominantly archaic. To resolve the crisis of hegemony in backward countries, it would be understood, according to the raised thing, as the articulation of a project of national development in function or according to the prevailing Capitalist Phase.

\section{Underdevelopment in Brazil: hegemonic crisis from the Social Imperialism to the Capitalism of Knowledge}

Brazil occupies a preponderant place in the study of Latin American countries, due to the processes and socioeconomic transformations in which it has been immersed for more than a century. Thus, despite dragging the historical burden of the most degrading acts such as colonialism and slavery, its economic trajectory, especially from the twenty-first century, also aimed to move incrementally on a path of development, orienting itself as emerging global power. However, the dominant classes have lacked the capacity to summon the rest of the social groups around an industrial development project under national premises, even at a time when the State substitutes the class for the purpose of industrialization. This section exposes how this unresolved crisis of the hegemonic function within the Brazilian corporate HB, explains the failure in the consolidation of Brazil as an

\footnotetext{
${ }^{16}$ Capacity of consensus implies capacity of direction, capacity of a class or social group to convince to the majority of the society on the justice of its historical aims.

${ }^{17}$ Ability to coerce is the ability to force, to constrain certain social groups to take as their own the historical objectives of the class exercised by the Hegemony.

18 "The conception of the full state presupposes taking into account all the means of intellectual and moral direction of a class on society, the way in which it can carry out its hegemony, even when it is the price of compromise equilibria tending to safeguard its own political power, particularly threatened in times of crisis" (Buci-Glucksman, 1979: 123).

19 The realization of this objective of unity of the State in its broad sense, Gramsci will tell us, requires a process of passive revolution in which the dominant classes obtain the passive or active consensus of the subaltern classes and eliminate antagonistic social forces from the incorporation of the historical interests and objectives of the subaltern classes, alien to the dominant classes and even contrary to them, thus achieving a consensus based on a future project that represents a real possibility of development for the subaltern classes.
} 
ascending regional power along three different Development Phases of the capitalist system, including the decade wasted at the beginning of this century in the broader framework of Knowledge Capitalism. ${ }^{20}$

\subsection{Incipient industrialization in the Social - Imperialism}

During the Socialist-Imperialist Development Phase, Brazil initiates the process of industrialization in an incipient way in the hands of the agro-exporting bourgeoisie, being first the sugar and then the coffee one the most important. The first stage of outward growth is reinforced in the government of the First Republic (18891930), a period in which the ruling classes "institutionalized" their hegemony within the HB, accessing state power with support for the dictatorship military that established the Velha Republic.

As a result of the hegemonic interests within the HB, during this stage a liberal-oligarchic state was established in Brazil, forging an alliance between the hegemonic fraction and the incipient industrial bourgeoisie around the outward growth project. This agreement allowed the coexistence of the dominant groups based on a limited action of the State that facilitated a cyclical strategy for the mutual benefit of both groups. The complementary relationship between the two bourgeoisies was expressed in what Marini (1975: 11) calls a "State of commitment", as a specificity of the liberal-oligarchic state, lacking an active participation in the process of industrialization (Baer, 2008).

In the international context, in the interval of transition between the Social Development Phase-Imperialist and the Fordism-Keynesian, a set of changes was presented such as the world crisis of 1929, the warlike conflict of the First World War and the emergence of a new technological revolution and work organization ${ }^{21}$.

During this period, the industrial bourgeoisie gradually gained greater preponderance and independence from the agrarian bourgeoisie; Some industries emerged outside the circle of influence of coffee cultivation such as cement, rubber products, agricultural machinery, iron and steel, paper, silk and other textiles (Villela 2011: 42). This industrial advance brought with it a growing middle class, among which the civil and military bureaucracy stood out, as well as the commercial and industrial bourgeoisie with interests opposed to the coffee growers, who together exerted an important pressure on the State.

\subsection{Passive revolution and industrialization in Fordism - Keynesian}

Derived from the above, a process of passive revolution takes place, in which the State replaces the ruling class in the process of industrialization, covering the period known as the Estado Nôvo (1937-1945), which lasted until 1950. The objective is to create the bases for the reproduction of the industrial capitalist accumulation, adopting as a way of development the strategy of Industrialization by Substitution of Imports (ISI), which involved investing in infrastructure and production, expanding the credit, redistributing the profits and regulating the price of work.

This new action of the State in a restricted sense leads to recalibrate the specific weights of social groups within the corporate HB, which is conformed by the agrarian - exporting and landowner bourgeoisies that remain dominant, but with a power diminished by the continuous rise of the different fractions of the industrial bourgeoisie $^{22}$ in association with the merchant or mercantile bourgeoisie (importing merchant groups), and the proletariat benefited by a whole series of social concessions. The corporate character of the State is articulated

\footnotetext{
${ }^{20}$ We understand by Knowledge Capitalism to the new Development Phase of the capitalist mode of production, studied from the perspective of its long-term cyclicality. This phase is the result of the transition of the capitalist system in order to overcome the historical crisis of the previous phase (Keynesian Fordism) that occurs in the second half of the sixties and early seventies of the previous century and thus prevail as a mode of production. This new phase has involved the use of the technological revolution of the microprocessor and software and its articulation with Toyotism as a form of organization and direction of work, elements that allowed the valorization of empirical knowledge of the worker to form a new technological - productive base. This base meant the emergence of a complex of industries, products and services, which currently articulate and dynamize economic growth (industrial pattern), identified as the Electronic Information and Telecommunications Sector (SEIT) (Ordóñez, 2004). To this configuration corresponds a new supranational scalar or globalization, in which a differentiated geographical development is appreciated depending on the specific form of insertion of the countries to this Phase.

${ }^{21}$ The technological revolution that gives rise to the new Development Phase or Keynesian Fordism (1933-1980) has as central elements the consolidation of the electrified factory, the chemical industry, the steel and the steam turbine (Dabat, 2014; Ordoñez, 2004).

${ }^{22}$ Ianni (1971: 99) characterizes the industrial bourgeoisie as: the industrial petty bourgeoisie, linked to the production of traditional products; the great industrial bourgeoisie, which maintains ties with the agricultural sector, the great export and import trade and financial capital; and the great international industrial bourgeoisie, arising from the investments of foreign capital and the first capital associations.
} 
through its own technical bodies, facilitating the representation of the interests of the industrial bourgeoisie; while corporate unions are formed that allow the consolidation of the Labor Laws.

Until the 1950s the economic policy of "complementarity" continues to operate, but this is exhausted due to the fall in demand for traditional Brazilian exports by the United States, a situation that strains the commitment between the agro - exporting, landowning bourgeoisies and industrial. The conflict between the ruling classes spreads to the lower strata of the HB through an increase in inflation derived from the fall in the supply of raw materials and food, product of the lag in the productive capacity of the field and the concentration of land by the landowners. This increases the union pressure and in the countryside the fights for the possession of the land are intensified. It is then an implicit pact between the industrial bourgeoisie and the subaltern classes to cancel the agreements with the agrarian bourgeoisie. The pact is covered by a nationalist ideology in the second period of the government of Getulio Vargas (1951-1954).

The result was a new impulse to the industrialization that occurs from the increase of the public investment through the creation of the National Bank of Economic Development; the orientation of public resources to the health, food, transport and energy sectors through the Salte Plan; the National Road Plan and the National Electrification Fund; the re-equipment of the merchant marine and the port system; Petrobrás dedicated to petroleum as well as the Electrobrás electric power project (Marini, 1975: 28-29). Data from Ianni (1971), show the rates of change of indices of the real product of the agricultural and industrial sectors in the period 1940-1960, result of public investments on industrial production for the domestic market (see Figure 1).

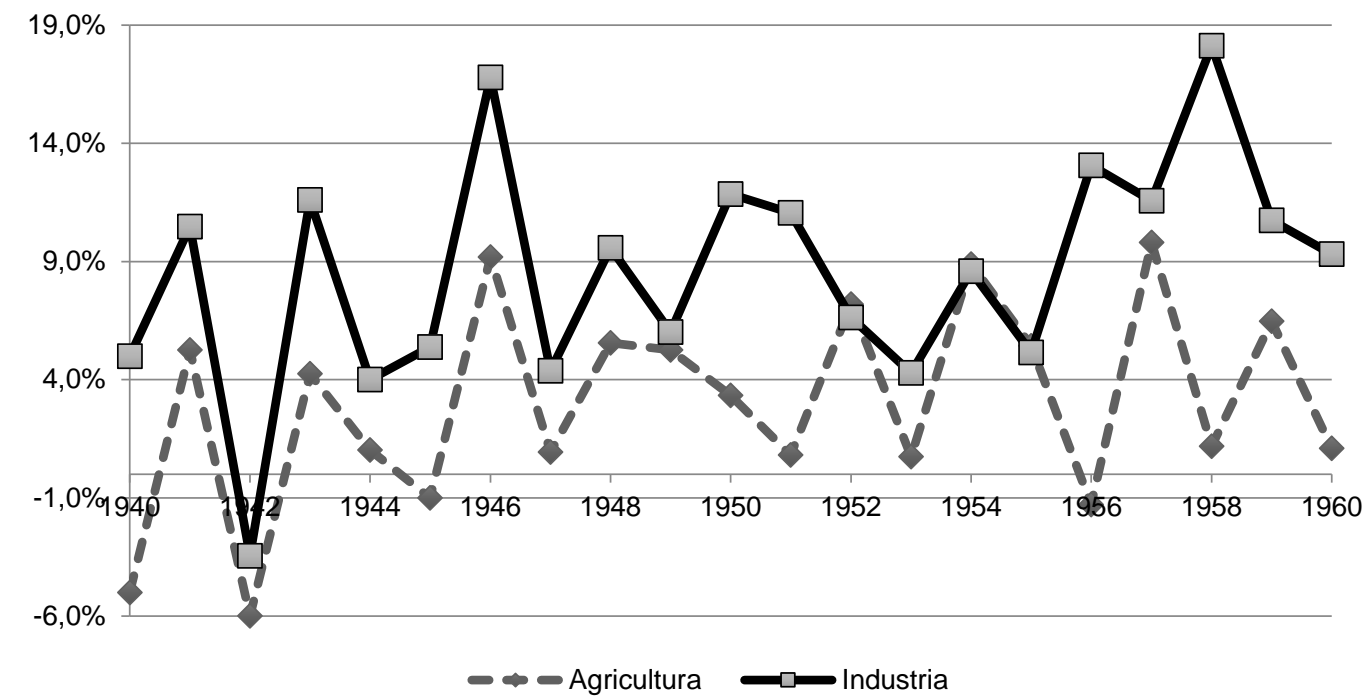

Figure 1. Brazil: Exchange rates of the real product of the agricultural and industrial sectors

Source: elaborated with data from Ianni (1971: 137).

These nationalist policies intensified the struggle between the main dominant fractions: the agro-exporting and landowning bourgeoisies in main opposition to the nationalist industrial bourgeoisie ${ }^{23}$. Between 1955 and 1964, the developmental character of the State is accentuated; Electrobrás and Embratel are established as state-owned electric and telephone companies, and the take-off of the Brazilian automotive industry begins, the National Bank for Economic Development (BNDE) becomes the main source of long-term investment loans.

However, the rise of the national industrial bourgeoisie as a hegemonic fraction was limited by the reluctance of the landowning groups to yield to the realization of an agrarian reform promoted during the João Goulart government, which would have allowed the expansion of the internal market for the industrialists. To the struggle between dominant classes, there was an overflow 'down', because before the increase of the migration field-city, the wages in the cities fell.

\footnotetext{
${ }^{23}$ To this is added the enactment of Instruction 113 during 1955, which facilitated the entry of foreign capital, particularly from the United States, which strengthens the ties of the big industrial bourgeoisie with international financial capital, deepening internal fissures among the industrial sector.
} 


\subsection{Hegemonic crisis and truncated industrialization}

To the hegemonic crisis of the agro - exporting landowning bourgeoisie, a progressive political-military solution in favor of industrialization is imposed, represented by the coup d'état in Brazil that the military dictatorship established in 1964. From that year until 1990, it consolidates what Evans (1984) calls a "triple alliance" between the transnationals, the dominant fraction of the industrial sector and the State. The role of state companies is strengthened, increasing in sectors such as aeronautics and telecommunications (Embraer and Telebrás, respectively). During this stage, the State seeks to integrate multinational companies in a "nationalist accumulation" scheme.

However, the industrial groups that benefited from this experience were the largest and some small industries in the petrochemical sector, widening the gap between the big industrial bourgeoisie with strong ties to foreign capital and a weak nationalist industrial bourgeoisie.

The promotion of state enterprises together with the expansion of the multinationals and their association with the dominant fractions of the industrial bourgeoisie, as well as the weakening of working conditions of the subaltern classes (Knox, 2001), deepened the fissures between the fractions of the industrial bourgeoisie inside the HB. The landowning and agro-mining bourgeoisies maintained an important position in the economic structure, due to the stabilization of the prices of the agro-mining sector, which kept the value of exports above the value of the industrial sector during almost all the decade of the seventies (see Figure 2).

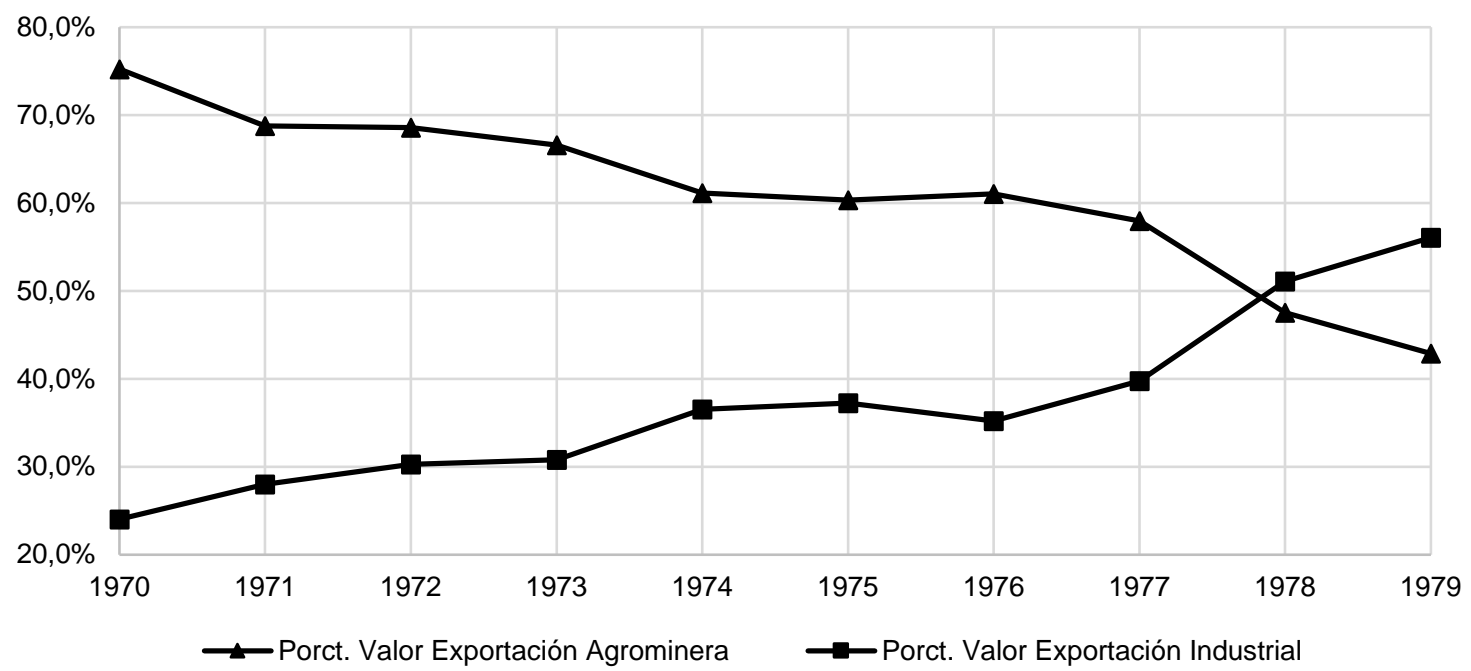

Figure 2. Brazil: Value of agrometer and industrial exports 1970-1979. Percentage evolution by sector

Source: elaborated with data of Araújo (1980).

In this condition of unresolved crisis of the hegemonic function within the industrial HB, the State fails in the attack of industrialization and its action becomes insufficient before the incapacity of consensus of the dominant bourgeoisies to direct the process of national development. Then, in a state of weakness of the State, the neoliberal wave will be imposed by a set of public policies synthesized in the Washington consensus, aimed at eroding the active role of the State in the economy during the last decade of the twentieth century.

\subsection{Fractured state, boom and neoliberal decline}

A process of deindustrialization was initiated in which the bourgeoisie linked to sectors oriented to the processing of natural resources ${ }^{24}$ displaced the industrial bourgeoisie, forcing it to partially or completely replace its productive activities by importing or reselling the products it manufactured, or by selling it for sale or opening of its companies to foreign capital and assigning it a mere rentier function. During 1996 and 1997, the agro-industrial export bourgeoisie benefited from the export tax exemption and the increase in the prices of export products (tobacco, cocoa, coffee and soybeans). The flexibilization of the labor market, the reduction

\footnotetext{
${ }^{24}$ The dominant bourgeoisie was made up of monopolistic industrial groups linked to the processing of natural resources such as Ipiranga (oil), Fósfertil (petrochemicals), Vicunha (steel), Gerdau (steel), Votorantim (metals and cement) and infrastructure such as the Odebrecht groups and Andrade Gutiérrez (Boito, 1998); In addition to the banking arms of large agro-exporter groups, such as Bozano Simonsen.
} 
of salaries and the stagnation of social spending, completed the picture of economic and social deterioration in the country, a context that questioned the hegemonic function of the dominant groups, lacking sufficient capacity to call to include the aspirations of the subaltern groups in a vision of the future. This crisis of hegemony leads to a political-social fracture within the HB, expressed in a crisis of the economic actions of the State or Fractured State.

But at the end of the 1990s, neoliberal development showed its exhaustion in Brazil with the so-called "exchange crisis" that ended up negatively impacting the main macroeconomic variables of the country. The strategy of the Real Plan ${ }^{25}$ to stabilize prices from high interest rates and capital inflows, generated a constant negative balance of the trade balance in the nineties. With low economic growth, a quasi-exponential growth of the external debt began as of 1992. In this context, in 1999 the free floating of the real's price against the dollar took place, which implied a devaluation of the real of 60 percent (Sáinz \& Calcagno, 1999: 71-72), as well as the end of the Real Plan.

This scenario strengthened the popular support of the union and peasant organizations. The Single Confederation of Workers (CUT) created in 1983 and the Landless Movement (MST) of 1979, in addition to the National Conference of the Bishops of Brazil (CNBB) became engines of social mobilization and main allies of the Party of the Workers (PT), that later would obtain political advantage taking Luiz Inácio Lula da Silva to the presidency in 2002. The process of struggle between the main groups and ruling classes of the previously consolidated HB intensifies, provoking a national process of internal convulsion that meant the return of the State in the search for an alternative development path to neoliberalism ${ }^{26}$.

\subsection{Lulismo: neo-development and wasted decade}

The action of the State in a restricted sense before the weak internal hegemonic function, was synthesized in the neo-development as a development path in the Knowledge Capitalism, focusing mainly against the processes of international value transfer based on two strategies: the promotion of a relative industrialization by import substitution, aimed at increasing employment and expanding the coverage of social programs; and the application of tax rates to short-term financial capital in order to inhibit its entry into the economy, encouraged by the high interest rates derived from the anti-inflationary policy.

While the most important advances were made in the energy area, particularly in the biofuels industry such as ethanol, Brazil positioned itself above the OECD countries in the use of renewable energies based on the intensive use of biomass and electricity, which combined accounted for 45.8 percent of the country's energy production in 2007 (Van Kleef et al., 2012: 38-40). Important advances were also made in the oil industry, driven by the learning and development of technology destined for deepwater exploration by Petrobras.

Since the beginning of the new century, Brazil has made important efforts in the development of a computer and telecommunications infrastructure, making an investment in equipment in this sector that represents more than 20 percent of the total investment since 2003 (Ordoñez, 2013: 24). Regarding the access and widespread use of new technologies, there is progress in the adoption of mobile devices and internet use, but the country has a significant lag (see Figure 3). The latter becomes relevant because within the new capitalist phase, network technology will be the main source for increasing productivity through the processing of knowledge translated into information and communication (Castells, 2011: 43).

\footnotetext{
${ }^{25}$ The Real Plan consisted of a balanced budget, an annual process of general indexation of prices, including wages, as well as the introduction of a new currency: the real one; measures that were the prelude to the opening of the economy to international trade and financial flows (Van Kleef et al., 2012).

${ }^{26}$ The neoliberal (Atlantic-hegemonic) development path was the strategy under which the United States is inserted into the new Phase as a result of the impulse of the new technological - productive base under the torrent of risk capital available in the decade of the eighties. and that presented its highest peak in the last decade of the 20th century; However, the continuous process of separation between the productive and financial capital, from the development of financial securitization instruments as well as the emergence and boom of the shadow banking system (Shadow Banking System), meant a brake on the subsequent structural deployment of the current Phase and the consequent crisis of neoliberalism as a development path, which presented its most recent turning point in the global financial crisis of 2007-2008, from which until now there are no strong indicators of economic recovery. As will be shown, the less developed countries, such as Brazil and Argentina, faced with the failure of industrialization due to import substitution and in the context of the crises that occurred in the 1980s, had a limited margin of maneuver to build a road alternative development, so they were also inserted into the new phase under this neoliberal path, the result of a fractured state.
} 


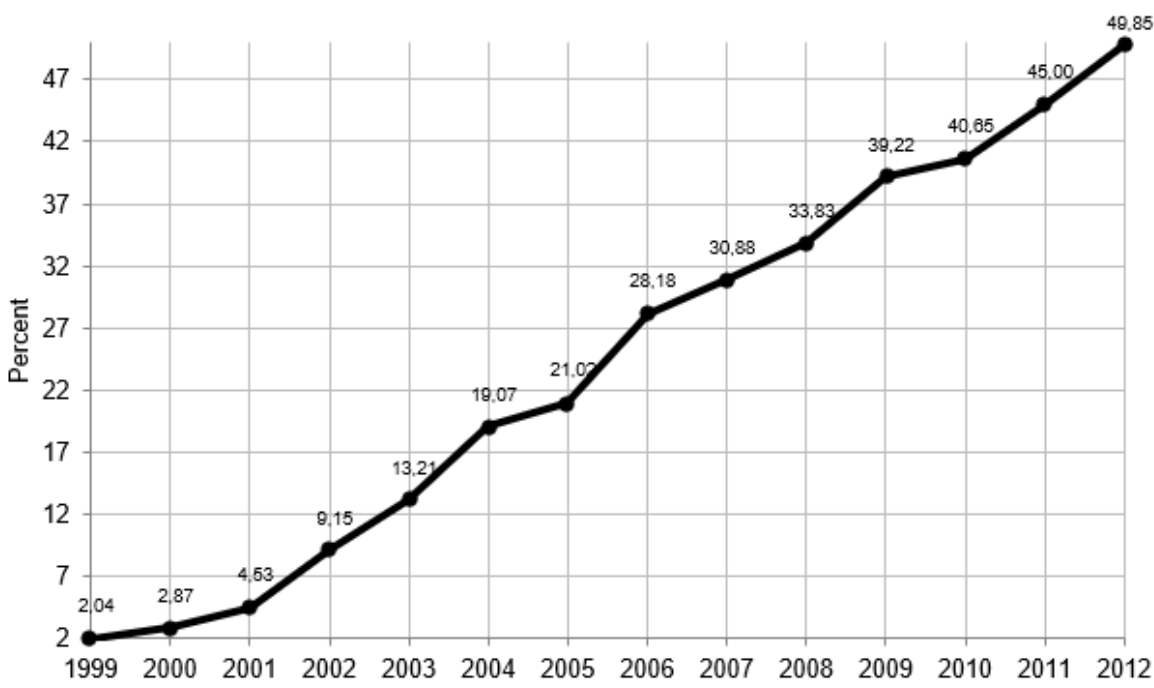

Figure 3. Brazil: Internet users, 1999 - 2012

Source: elaborated with data from CEPAL, 2016.

On the other hand, the relative improvement in labor market conditions brought with it the growth of a new middle class that substantially increased its consumption power, reactivating the domestic market, boosting industry and reducing inequality and poverty (see Figure 4). Extreme poverty in Brazil fell from 12 percent in 2003 to 4.8 percent in 2008, with 20 million brazilians joining the middle class (Van Kleef et al., 2012: 33-34).

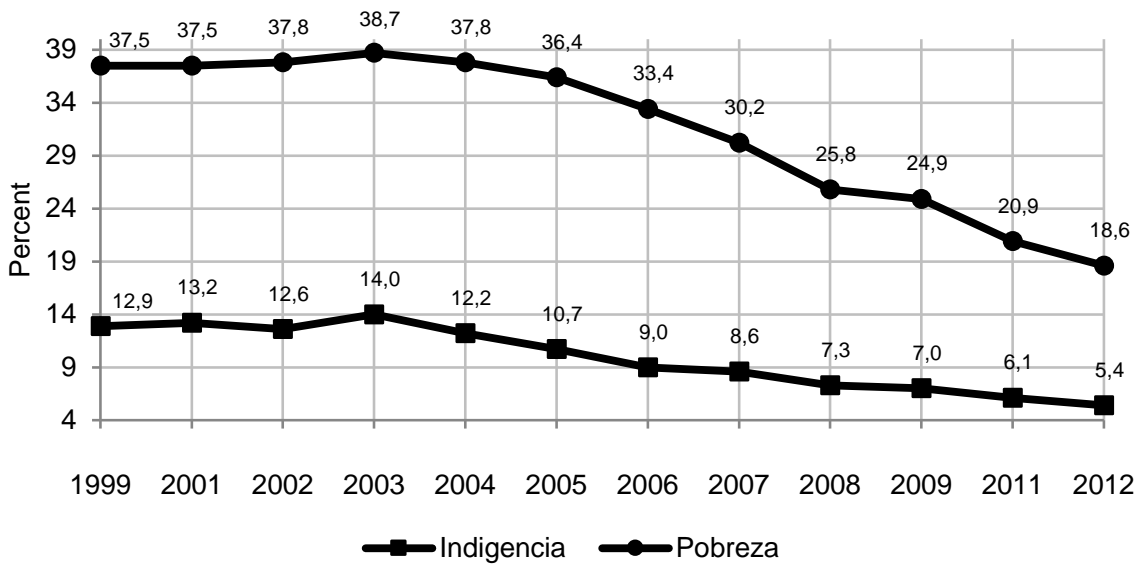

Figure 4. Brazil: Population living in poverty and poverty, 1990-2012

Source: elaborated with data from CEPAL, 2016.

In spite of the advances indicated above, in terms of physical infrastructure there was some stagnation, which limited the continued economic growth. Van Kleef et al. (2012) describe this lag focusing on transport, as a weak link that limits Brazil's competitiveness on a global scale. Only 10 percent of roads are paved; the railway system is not integrated; the channel system is inadequate; the ports, through which 95 percent of exports pass, are outdated; and airports operate within their capacity limits. As of 2007, the accelerated growth program was promoted, with an investment of 763 billion dollars, with scope until 2014, but the initiative did not have the expected results.

After the entry of Dilma Rousseff as president of Brazil in 2011, also emanating from the PT, she continued with the axis of policies that Lula Da Silva had inaugurated. However, neo-development found its limits as an alternative path to neoliberalism in the Knowledge Capitalism, turning the period of its development into a wasted decade, leaving the crisis situation of the hegemonic function inside the brazilian corporate HB unresolved. 
This crisis is expressed in a recurrent inability to summon the dominant industrial groups to accord to the rest of the social classes around a national development project under the economic - structural conditions of the current Development Phase. In this sense, neo-development failed to not place as the center of its strategy the promotion and consolidation of a new endogenous cycle of knowledge, which allowed the subaltern classes not only to overcome the condition of poverty, but to actively participate in a project of national development, articulating the Educational Scientific Sector with the industrial sector and particularly the SEIT. In this sense, the efforts made in the scientific-educational sphere (Mercadante, 2013: 435-437), as well as in the deployment and generalized use of a computer and telecommunications infrastructure, in order to develop their own intellectual property through learning and innovation processes, it was late and insufficient, even more, the articulation of internal productive networks and their rise in global productive networks under the premise of the national scale. For this, a strong State action in its restricted sense was essential, in order to overcome the weak hegemonic function of the HB.

This lack of the State, derived in the historical continuity of the crisis of hegemony of the dominant groups and its expression in the manifestations of social discontent on the part of the subaltern classes, who did not find in the neo-development strategy enough room for their aspirations of progress social. The depletion of neo-development (Katz, 2015), will show the hegemonic and economic crisis that have dragged countries of late industrialization such as Brazil, continuing the struggle between the hegemonic fraction and rising social groups. The immediate result of the decade wasted in Brazil, was the impeachment of Rousseff at the end of 2015, the rounding up of Lula and the return to power of conservatism under the mandate of Michel Temer, canceling a new opportunity for Brazil to overcome the condition of underdevelopment in the Capitalism of Knowledge (Ramírez and Sztulwark, 2018). It is the end of the progressive cycle in Brazil, or the righting that is happening in different parts of the world (Modonesi, 2017).

\section{Underdevelopment in Argentina: hegemonic crisis from the Social Imperialism to the Knowledge Capitalism}

Due to its economic dimension, Argentina is part of the study of countries with greater relevance in Latin America. Its starting point as a nation arises as a result of European immigration in the pampera region in the 19th century, as this meant a determining factor for the formation of a bourgeois landlord class that throughout the 20th century managed to consolidate its dominance over the rest of the fractions and class groups, even neutralizing the efforts of the State to carry out a process of national industrialization.

\subsection{Incipient industrialization in the Social - Imperialism}

Within the framework of the Phase of Social Development-Imperialist, under the dominion of England as a world hegemonic power, the first stage of the process of industrialization is located in Argentina between 1860 and 1930, and it extends until 1943 as a consequence of the crisis of 1929. The South American country is integrated into the international division of labor by increasing the demand for livestock and agricultural products by central countries, which provided the impetus for the development of an incipient industrial sector around the development and conservation of products ${ }^{27}$; this sector reached 20 percent of GDP prior to the crisis.

During this stage, the HB is composed of a landowning and agricultural-exporting bourgeoisie as a hegemonic fraction, and its organic intellectuals ${ }^{28}$ who are positioned in the government bureaucracy, the Parliament and Courts of Justice; the subaltern classes were made up of landless laborers, braceros and workers from an incipient and little concentrated industry who sought economic benefits by inserting themselves in the lower parts of the value chains of the outward growth model. This composition of classes was projected in an oligarchic State as a state formation.

In response to the world economic crisis of 1929, the dominant fraction of the agrarian bourgeoisie carried out a reorientation of the economic policy implemented from the Roca-Runciman pact between Argentina and Great Britain in 1933. The pact guaranteed the continuity of exports without restrictions of chilled beef from Argentina, as well as the freezing of customs duties for products imported from Great Britain, thus strengthening the predominance of the dominant fraction of the agricultural bourgeoisie. In response, the subordinate

\footnotetext{
${ }^{27}$ These processing and conservation industries were: refrigeration, flour, oil, breweries, alcoholic beverages; factories of washing of wool, preparation of leather, tobacco and agricultural machinery to a lesser extent.

${ }^{28}$ This set of Intellectuals was composed of a select group of men from the University of Buenos Aires who belonged to the landowning class or were related to livestock and agricultural activities
} 
industrial bourgeoisie, in coordination with the subaltern groups under its sphere of influence, carried out a campaign of pressure on the government, which resulted in a set of measures to protect the sector by the State, which were summarized in an Economic Restructuring Plan. The Plan included a control of foreign currency for imports as a compensatory measure for the devaluation of the argentine peso which had favored the exporting agricultural and livestock bourgeoisie and increased the purchase of raw materials abroad by industrialists; the creation of Production Regulatory Boards; as well as the development of a public works program (Mumis \& Portanteiro, 2004: 70-73).

To the discontent among industrial groups, within the framework of limited industrialization subjected to a process of capitalist accumulation without income distribution, the dissatisfaction of the unions was added to the extent that this model did not prioritize the expansion of the internal market, however the government's refusal to involve trade unions in decision-making; as well as the improvement of working conditions, they represented additional factors for the exhaustion of the limited industrialization model (Peralta, 2007: 91).

\subsection{Passive revolution and industrialization in Fordism - Keynesian}

The previous scenario, where the mobilizations of the workers and the demands of the fraction of the displaced industrial bourgeoisie, that is, of the subaltern classes within the HB, constitute a process of passive revolution, which allows the State to assume the representation of interest social with greater political-economic autonomy to promote the project of national industrialization from a new state activism.

Thus, the second stage of the argentine industrialization process is located between 1943 and 1965, where the Argentine State appeared as a decisive protagonist in the economic process: it transferred resources from the agricultural sector to the industrial sector to promote specific sectors, developed non-tariff mechanisms, promoted the redistribution of income and reduced the participation of foreign capital to a historical minimum (Peralta, 2007: 96; Ferrer, 2010: 122). Also, the unions became the means of participation of the working class to influence the economic activity of the country from its corporatization, guaranteeing the governance that the State required to promote the national development project.

During this process of industrialization, the correlation of forces within the corporate HB was determined by the landowning and agro-exporting bourgeoisie, in addition to the traditional industrial bourgeoisie in the dominant fraction; while in the middle section was the new industrial bourgeoisie ${ }^{29}$ and, finally, the workers and peasants as a subaltern class.

The nationalization of foreign capital and the measures designed to diminish the economic power and the influence of the most powerful fractions of the agricultural and industrial sectors during the Peronism, provoked a systematic opposition of these sectors to the government. The subsequent control of the State by these fractions (1955-1965) inaugurated a coalition of ruling classes with the capacity to neutralize, invalidate and deactivate the economic interventionism that the Argentine government had implemented to accelerate the process of national industrialization. It had to weaken union power, redistribute income for the benefit of groups affected by nationalist politics, link the country with international financial and economic circuits and dismantle an important part of the interventionist apparatus mounted by Peronism. Until 1966, the models of development promoted by the two main ruling groups of the bourgeoisie coexisted in open struggle: on the one hand, the agricultural sector and, on the other, the big industrial bourgeoisie, now with greater power, seeking to implement a development model from the most intensive branches of capital, with strong subsidies, high tariff protection, incorporation of technology and foreign capital.

\subsection{Hegemonic crisis and truncated industrialization}

The last stage of the process of industrialization by import substitution, which goes from 1966 to 1976, develops from the HB formed by an industrial bourgeoisie linked to transnational capital and a landowning bourgeoisie - agroexporting as a dominant fraction; while in the middle section there was an industrial and nationalist bourgeoisie, and the subaltern faction composed of workers and peasants. The conflict was carried out by dominant groups of the industrial bourgeoisie with strong ties with foreign companies, the financial sector and state companies.

This stage was characterized by a systematic State intervention in the economy, but eliminating the redistributive component that characterized the ISI model during Peronism: tax exemption and a process of export

\footnotetext{
${ }^{29}$ Conformed of small and medium entrepreneurs linked to the most dynamic manufacturing branches of industrial activity.
} 
substitution was promoted, that is, an increase in exports of the branches that led industrial development; the above according to the industrial pattern of the Fordist - Keynesian Development Phase. Within the framework of strong tariff protection, the expansion of the industrial capacity of these companies was carried out from the installation of technologies developed in advanced countries. The State promoted industrial projects to produce locally the basic inputs for production and thus reduce the country's strong dependence on importing them.

The crisis of hegemony of the industrial HB 'above' in Argentina, located in this third stage of the process of industrialization, is composed of these two elements: insufficient capacity to call and consensus of the dominant industrial bourgeoisie to postulate and direct an industrialization project national as well as guiding the whole of social action around it. Additionally, it is exacerbated by the 'bottom-up' social spillover from Argentina's HB with the rise of mobilizations of the subaltern fraction - workers - for wage demands that took place in Perón's brief return to power at the end of 1973. The defeat of the Peronist government and the entry of the new dictatorship, meant a social-political fracture within the HB, expressed in the cancellation of the industrialization project and a crisis in the economic actions of the Fractured State or State.

\subsection{Fractured state, boom and decline neoliberal}

Under the previous scenario, the configuration of the new path of neoliberal development in Argentina was articulated from the corporate HB, whose ruling classes, in conditions of hegemonic crisis, were made up of an export group of agricultural raw materials, dominant in the sectors of food, textiles and petrochemicals, causing a strong influence on the beginnings of the government of Carlos Menem. Using the instruments of the State, the dominant exporting faction maneuvered to diminish the economic power of the industrial bourgeoisie, in particular of the so-called 'contractor homeland ${ }^{30}$ ', formed by the economic groups that had benefited in an extraordinary way as suppliers and/or State contractors. In addition, the commitment to classes and subaltern groups was broken, manifested in the frustration of the expectations of the popular sectors that had voted for Peronism.

Neoliberalism took hold as the alliance of the agro-export bourgeoisie with international financial capital and transnational productive capital, a pact that favored the permanence of domination by the national capitalists located in the agroindustry, was implemented in 1991 through the Plan of Convertibility, generating a direct attack on the active participation of the State in the economy, promoting neoliberalism as a project in which the market forces will govern the generation and distribution of the national economic surplus in a preponderant manner. In this sense, the government began in 1990 the privatization of state-owned companies of greater relevance (telephony, air navigation, electricity, gas and state steel, oil).

In the area of the banking sector, which at the end of 1994 had 169 entities, was reduced in mid-1999 to 96 entities, due to processes of centralization of capital, however groups of foreign capital registered an increase, in the same period, from 31 to 42 entities. The increase in the presence of foreign capital, as allied groups of the HB agro-exporter, was reflected in the composition of exports, since by 1998 the 49 percent of the exported product corresponded to the one hundred transnational exporting companies, reducing the intervention in the generation and export of national capital value.

However, at the beginning of the new century, the exhaustion of the neoliberal development model with the so-called 'exchange crisis' was evident, causing an environment of economic recession. To the above is added the discontent of the industrial bourgeoisie harmed by the commercial opening and an atmosphere of protest in the subaltern classes against the economic model that increased unemployment.

The scenario of economic crisis permeated the different social groups ${ }^{31}$, generating expressions of strong social discontent. The protests of 2001 and early 2002, under the slogan 'Everyone leaves', added to the internal struggle of the ruling classes of the HB provoking the consecutive relief of five presidents in just thirteen days.

\footnotetext{
${ }^{30}$ The government adopted a series of measures aimed at removing economic and political power from the most concentrated sectors of the industry. Among these measures, it is worth mentioning the approval of the Economic Emergency and State Reform laws. In response, this sector triggered exchange rate runs, inflationary escalations and pressures on the national cabinet controlled by the export bourgeoisie (Peralta, 2007: 312).

${ }^{31}$ Poverty went from 38.3 percent of the total population in October 2001 to 57.5 percent one year later. Extreme poverty reached 27 percent of the population in 2002, more than double the previous year. This caused the emergence of "new poor". This social stratum was made up of suddenly impoverished members of the lower middle class and the upper working class, survivors of the declining public spending and rising unemployment of the 1990s. This new piquetero movement did not belong to the historical social stratum of marginalization and structural poverty, but was a consequence of the dismantling of the country's salaried working class (Grugel \& Riggirozzi, 2007: 94-95).
} 
This process of internal convulsion represented an opportunity for the search of an alternative development path to neoliberalism in Argentina.

\subsection{Kirchnerism: neo-development and wasted decade}

The crisis situation in Argentina opened the space for the rise of the productive group headed by the Argentine Industrial Union over the agro-mining landowning bourgeoisie allied with financial capital (Peralta, 2007: 380), neo-development emerging as an alternative way of development, considering the 'installation of a competitive productivist model' (Curia, 2007). The rise of this productive group implied a state action in a restricted sense to compensate the now unstable hegemonic function of the dominant classes that make up the agroexporting HB, which was in the framework of the argentine economic crisis. From this action, a process of intermediation of integration in the world market was promoted in relation to internal accumulation to favor the maximization of economic growth, a process in which the relative reorientation of the accumulation started from the financial recovery until the productive valorization, leaving aside the obsession with inflation control and formulating a process of substitution of imports and exports that favored, to a certain extent, the reindustrialization of the country. In this process, the incorporation of the working class was facilitated, partially, through a policy of collective bargaining and tripartite negotiation, achieving the distribution of productivity increases between wages and profits (Grugel \& Riggirozzi, 2007: 102-103).

Even with the arrival of Néstor Kirchner to the presidency of the country, the industrial bourgeoisie linked to transnational capital and the landowner-agro-export bourgeoisie remained as dominant fractions within the $\mathrm{HB}$, and it was until the mandate of Cristina Fernández that they lost that dominant position, that it served so that the Kirchner government left behind its ambiguities, abandoned the transformism and finally assumed its clear aspiration to grant social benefits to the various subaltern sectors (Dagatti, 2013).

In these conditions the resolution to the hegemonic and economic crisis was sought, in addition to the crystallization of the kirchnerist political project as a way to resolve the contradictions between the structure and the capitalist superstructure. However, the main postulates of neo-development, such as the use of commercial globalization to move towards export industrialization, the productive transformation with equity, the national development strategy, the direction that the State should take on and the consolidation of a bourgeoisie around to these objectives, with a view to leading the country towards convergence, it did not materialize even in the moments of greatest Argentine economic splendor.

Although the Argentine economy grew at an average rate of 8.5 percent in the period 2003-2008, it was paralyzed in 2009 as a result of the international financial crisis and returned to growth rates higher than eight percent in the following two years (see Figure 5), this impulse was not oriented towards the development and strengthening of the determinants of reproduction and economic development in the Knowledge Capitalism.

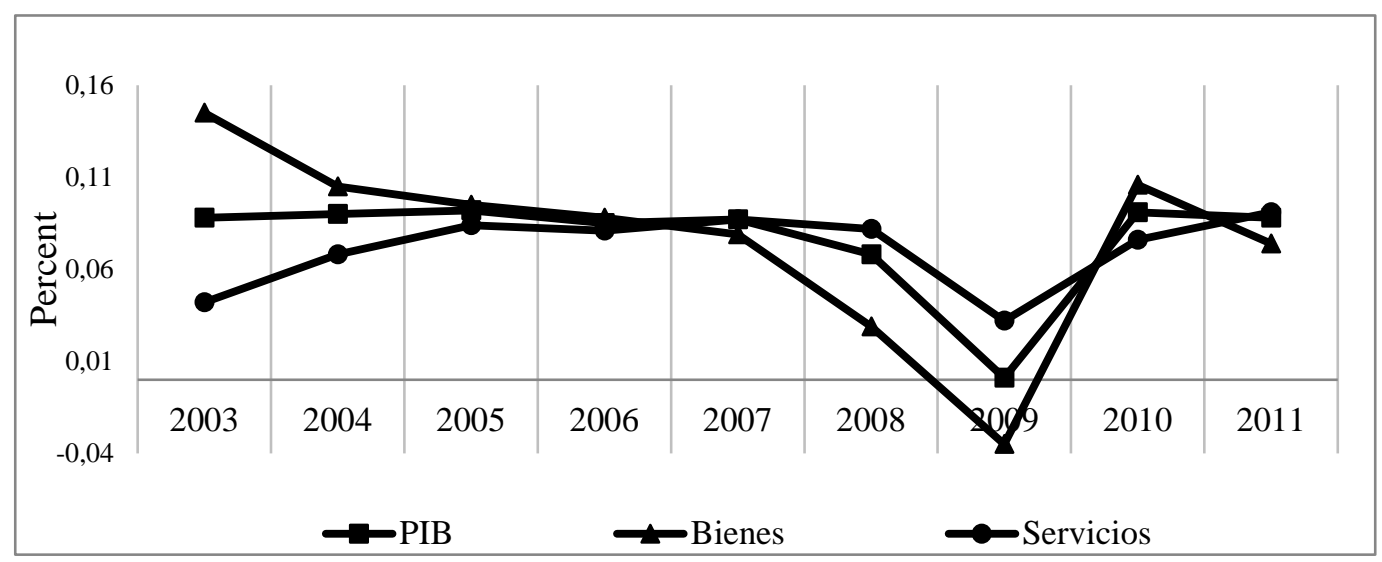

Figure 5. Argentina: Average growth rates of GDP and by sector, 2003-2011

Source: elaborated with data from INDEC, 2013.

In this sense, Argentina showed insufficient progress in the deployment of a computer and telecommunications infrastructure, in addition to its access and widespread use. During the Kirchner period, there were increases in spending on research and development, a process that was truncated and partially reversed in the face of the global crisis of 2007-2008 (see Figure 6). 
The development of physical and energy infrastructure is related to the re-nationalization of companies from different areas: in air transport, Aerolíneas Argentinas and Austral, formerly in the hands of the Spanish group Marsans, passed to the State's control in 2008; distribution of drinking water and sewage treatment, Agua y Saneamientos Argentinos (AySA), concessioned to the French group Suez, the Spanish company Aguas de Barcelona and the national group Banco Galicia, are nationalized 9 percent in 2006, 1 percent the remaining one hundred is controlled by the workers, while the operational control is in charge of the National Federation of Workers of Sanitary Works; radio spectrum and satellite communication, AR-SAT, controlled by the French Thales Spectrum, is under the responsibility of the State in 2004; maritime transport, Naval Workshops Dársena Norte (Tandanor), nationalized again in 2007 granting 10 percent of the shares to workers; land transport, San Martín Railroad and the Roca and Belgrano Sur lines, under state control since 2004 and 2007 respectively; hydrocarbon and petroleum deposits, Energía Argentina S.A. (Enarsa) and Yacimientos Petrolíferos Fiscales (YPF), created the first in 2004 and partially expropriated the second in 2012; mail service, Official Mail of the Argentine Republic, concessioned to the local Macri Group and retaken by the State in 2003. In these infrastructural areas, it would be expected a significant increase in investment and state management, which was not carried out with determination.

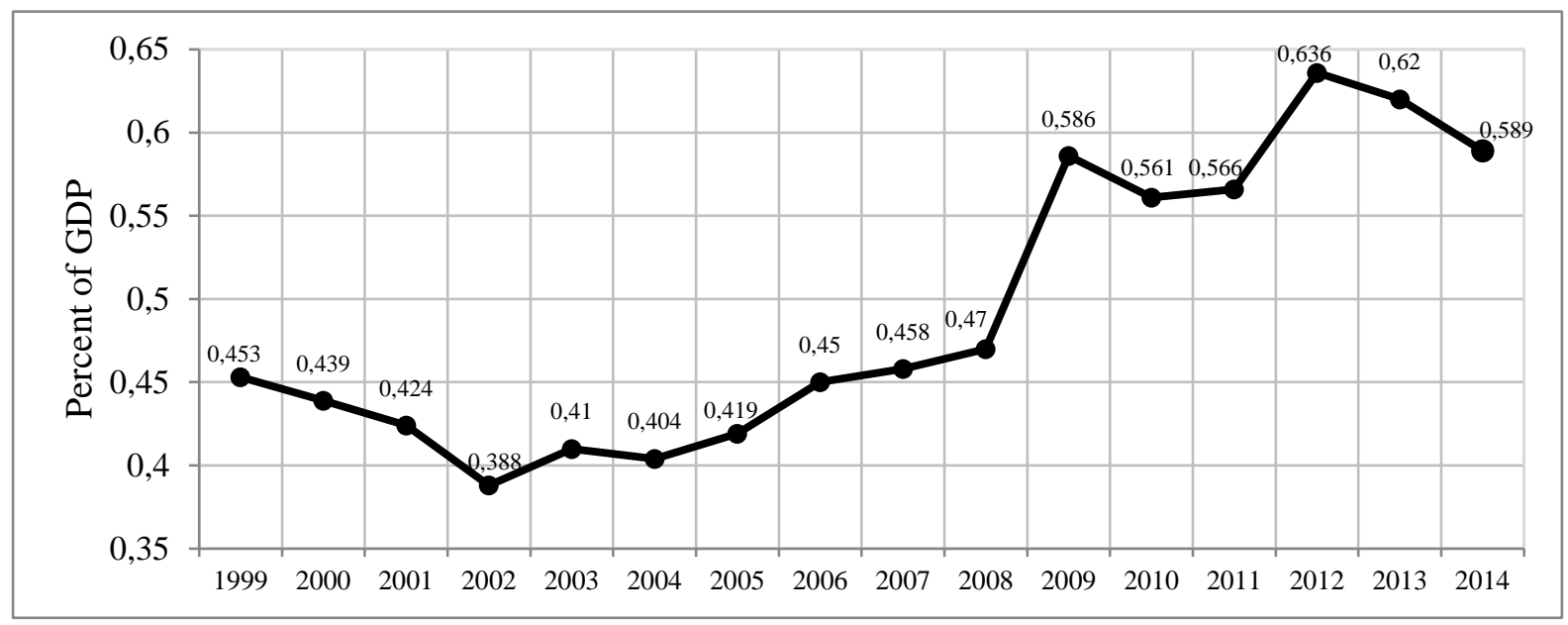

Figure 6. Argentina: spending on research and development, 1999-2014

Source: elaborated with data from the World Bank, 2017.

Regarding the physical and cognitive reproduction of the labor force, it implies the development of complex work $^{32}$, there was also a scarce state action. The programs of social inclusion were oriented mainly to guarantee the physical reproduction of the work force, diminishing in an important way the inequality and the poverty. In this area, through the Ministry of Social Development and under the slogan 'Another economy is possible', the inclusion of subaltern classes was promoted through the generation of employment (see Figure 7), promoting and strengthening social enterprises, mutuals and cooperatives, through training and technical assistance to small companies, individual or collective, providing economic support or microcredit (Microcredit Community, 2012), thus constituting a support system for local and regional socioeconomic development initiatives.

\footnotetext{
${ }^{32}$ In the new phase of capitalism, knowledge as a central element to increase productivity will be linked to the increasingly intellectual nature of the workforce, seeking to consolidate what Marx called complex work.
} 


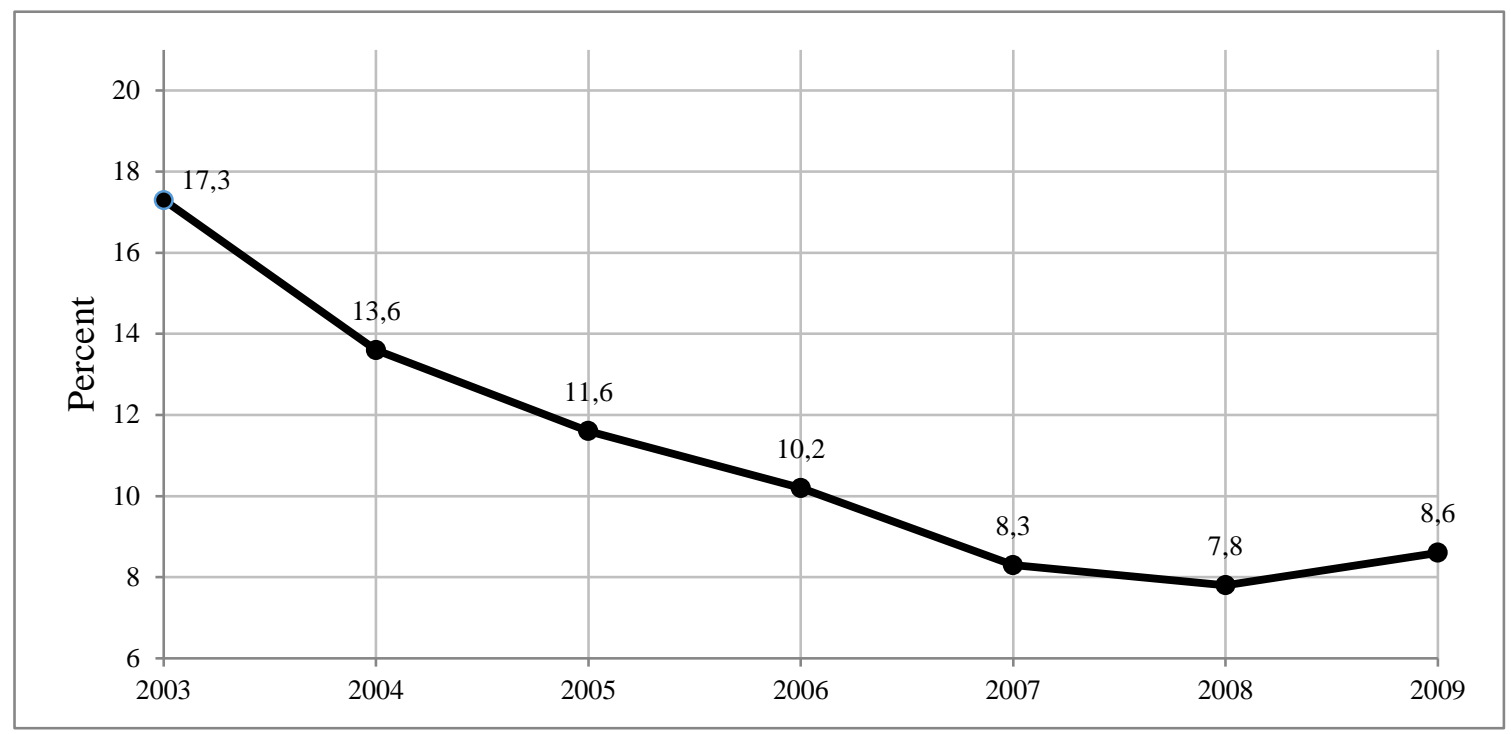

Figure 7. Argentina: Evolution of the unemployment rate, 2003-2009

Source: adapted from Repetto, F. and Potenza Dal Masetto, F., 2012: 7.

The insufficient state activism in a restricted sense that would have been necessary to overcome the crisis condition of hegemonic function of the industrial ruling classes around a national development project under the structural conditions of the new development phase, led to the rise of Mauricio Macri to the presidency in December 2015 (Rodriguez, 2015). The arrival of the engineer and businessman with a technocratic profile to power is outlined through the commitment to the 'change' of the subaltern classes, which represent sectors waiting passively for better social conditions on the part of the new political configuration, and not as an active social force that demands a greater civil participation in the reconfiguration of social forces within the corporate $\mathrm{HB}$ and that eventually results in a new state formation that retakes the representation of the social.

The end of the progressive cycle in Argentina (Modonesi, 2017) was more noticeable than in other economies of the Southern Cone, as Kirchnerism was already quite weakened by the presidential elections in 2015, which was reflected in the fact that the left candidate himself It was, Daniel Scioli, was away from the vision that had driven Cristina Fernandez de Kirchner. While in Brazil the return of the right was by a legal route, in Argentina was elected by the population itself in the voting, before the debacle of economic growth and corruption problems, which sealed the way of the formation of a State Expanded, in the Gramscian sense.

The social groups that mostly contributed to the triumph of Macri, are sectors that remain in expectation of better expectations by the new political configuration, but they remained more as spectators and not as a social force that demanded a greater civil participation in the reconfiguration of the Argentine State (PwC, 2016). With the end of Neo-development and Kirchner's ideological proposal that was developed since 2003, a wasteful decade is set for the aspirations of economic progress of the Argentine people under the prevalence of the unresolved hegemonic crisis of the Historic Block, as the ruling classes they do not call for the rest of the social body to agree on a development project within the framework of the new development phase of capitalism.

\section{Conclusions}

The withdrawal of the State in the economy after the debt crisis of 1982, opened the pattern of a deep process of economic stagnation and social inequality in Brazil and Argentina, ending by demonstrating its infeasibility with the exchange rate crises that broke out at the end of the decade. of the nineties in Brazil and Argentina, unleashing a series of massive social demonstrations that forced the dominant groups to propose an alternative way of development, without implying substantial changes in the correlation of forces within the historical blocks and taking advantage of the arrived at the governments of social leaders identified with the left to incorporate the most urgent social demands of the subaltern classes, in turn allowed them to retain their position of dominance.

This solution took shape in neo-development in the first decade of the new century, which implied the emergence of a social block made up of middle classes, neighborhood movements, cultural groups and the 
peasantry, which allowed us to weave new relations between State and society, from which a tenuous rupture with neoliberalism was achieved, expressed in a new state activism based on the agro-mining and oil income that mainly carried out an important social policy around the fight against hunger and poverty, in order to strengthen the market internal and boost consumption, as well as in the construction of physical and energy infrastructure that increased competitive capacities; while the impulse of a determined industrial policy continued to be ignored, giving instead a new encouragement to the exporting and landowner agro-mining bourgeoisies, who carried out a centralization in the most dynamic branches of the economy with the participation of transnational financial capital. .

The depletion of neo-development, precipitated fundamentally by the aftermath of the global financial crisis of 2008, exposes the fragility of the economic sustenance of this alternative path based again on exports of primary products, mainly due to the persistence of the hegemonic crisis in the interior of the national historical blocks. The neo-development was distinguished by the absence of an innovative national project, which was built from a new relationship between State, economy and society, that is, in the perspective of an enlarged gramscian State, which would overcome the historic struggle between the State and the market that has taken place in the Latin American region for decades.

This requires a new agreement, the overcoming of the condition of historical crisis of hegemony within the national historical blocks, between the agro-mining exporter and landowner fractions and the social blocks with participation of industrial sectors, having as a distinctive element the active role of the classes and subaltern groups as a hegemonic replacement factor. With the above, a counter-hegemonic struggle is not argued that seeks an exit from the capitalist mode of production, but a configuration of historical block that is prone to integrate the benefits of economic growth to broader layers of society, as demonstrated by other national experiences that have substantially reduced poverty and social inequality. The latter would mean the substrate of a new action of the State in the sense of promoting the process of construction of a new productive technological base that in turn implies the formation of an internal knowledge cycle, based on a social inclusion not based on the consumption, but cognitive productivist as an element of competitive differentiation, in the perspective of progress projects under the economic-structural conditions of this new phase of development.

\section{References}

1. Araújo, N. (1980). Crisis y lucha de clases en Brasil 1974 - 1979. (Tesis doctoral). Universidad Nacional Autónoma de México, Ciudad de México.

2. Baer, W. (2008). The Brazilian Economy. Growth and Development. Colorado: Lynne Rienner Publishers.

3. Banco Mundial (2017). Indicadores de ciencia y tecnología. Recuperado de https://datos.bancomundial.org/tema/ciencia-y-tecnologia.

4. Boito, A. (1998). Política neoliberal e sindicalismo no Brasil (Tesis doctoral), Universidade Estadual de Campinas, Campinas.

5. Buci-Glucksman, C. (1979). Primera parte, capítulo 3, apartado III: La concepción gramsciana de la ampliación del Estado. (Estado pleno) (pp. 121-142). Tercera parte, capítulo 3, apartado VI: Ampliación del Estado, bloque histórico y desaparición del Estado (pp. 351-360). En Gramsci y el Estado. (Hacia una teoría materialista de la filosofía). México: Siglo Veintiuno.

6. Castells, M. (2011). La Era de la Información: economía sociedad y cultura, Vol. 1, Madrid: Siglo XXI.

7. Comisión Económica para América Latina y el Caribe (2016). Estadísticas e indicadores sociales. Recuperado de http://estadisticas.cepal.org/cepalstat/WEB_CEPALSTAT/estadisticasIndicadores.asp?idioma $=$ e.

8. Comunidad Microcrédito (2012). Por una ley de economía social y solidaria en Argentina. Mendoza, Recuperado de http://www.microcredito.org.ar/noticia-830.html.

9. Curia, E. (2007). Teoría del modelo de desarrollo en Argentina, Ed. Galerna, Buenos Aires.

10. Dabat, A. (2014). Primera guerra mundial: antecedentes, consecuencias inmediatas y legado histórico al mundo actual. (En imprenta).

11. Dagatti, M. (2013). La refundación kirchnerista. Capitalismo, democracia y nación en el discurso de Néstor Kirchner, en Argentina después de la convertibilidad (2002-2011), Grigera, Juan (Comp.), Ed. Imago Mundi, Buenos Aires, Argentina.

12. Evans, P. (1984). El calzado, la OPIC y la indudable convicción: las empresas trasnacionales y las relaciones Estados Unidos - Brasil. En R. Fagen (Sel), Estado y clases sociales en las relaciones Estados Unidos - Latinoamérica (pp. 326 - 361). México: Centro de Investigación y Docencia Económicas, Fondo de Cultura Económica. 
13. Ferrer, A. (2010). El futuro de nuestro pasado: la economía argentina en su segundo centenario. Buenos Aires: Fondo de Cultura Económica.

14. Grugel, J. \& Riggirozzi, M. (2007). The return of the state in Argentina, International Affairs, 83(1), 87-107.

15. Ianni, O. (1971). Estado y planificación económica en Brasil (1930 - 1970). Buenos Aires: Amorrortu Editores.

16. Instituto Nacional de Estadística y Censos (INDEC) (2013). Centro Estadístico. Recuperado de http://www.indec.mecon.ar/.

17. Katz, C. (2015). ¿Qué es el neodesarrollismo? II: Una visión crítica. Argentina y Brasil, en Revista Serv. Soc., Abr. /jun. 2015, n. 122, São Paulo, Brasil, 224-249 pp.

18. Knox, B. (2001). Reassessing the Impact of Institutions on Economic Reform in Brazil. A thesis presented to the graduate school of the University of Florida in partial fulfillment of the requirements for the degree of Master of Arts, University of Florida.

19. Marini, R. (1975). Subdesarrollo y revolución, Siglo XXI, México.

20. Mercadante, A. (2013). Brasil: de Lula a Dilma (2003-2013), Madrid, Clave intelectual.

21. Modonesi, M. (2017). Revoluciones pasivas en América, Universidad Autónoma Metropolitana - ITACA, México.

22. Mumis, M. \& Portanteiro, J. (2004). Estudios sobre los orígenes del peronismo, Ed. Siglo XXI, Buenos Aires.

23. Ordoñez, S. (2004). La nueva fase de desarrollo y el capitalismo del conocimiento: elementos teóricos. Comercio exterior, (54)1, $4-17$.

24. Ordoñez, S. (2013). Repensando el Estado y el desarrollo en América Latina: en la búsqueda de una vía posneoliberal de desarrollo. En prensa.

25. Peralta, M. (2007). La economía política de Argentina: poder y clases sociales (1930-2006), Ed. Fondo de Cultura Económica, España.

26. Portelli, H. (1977). Gramsci y el Bloque Histórico. México: Siglo XXI.

27. PwC (2016). Los primeros 100 días del gobierno de Mauricio Macri, Buenos Aires, Argentina.

28. Ramírez, R. \& Sztulwark, S. (2018). América Latina: de la inmovilidad estructural al cambio en la matiz cognitiva, Revista Estado y Políticas Públicas, Núm. 10, Argentina.

29. Repetto, F. \& Potenza Dal Masetto, F. (2012). Sistemas de protección social en América Latina y el Caribe. Argentina, CEPAL-Sistemas de Protección Social en América Latina y el Caribe, colección Documentos de proyectos

30. Rodríguez, M. (2015). El nuevo gobierno de Macri, Ed. Papeles Fundación para el Análisis y los Estudios Sociales, España.

31. Rouquié, A. (1989). América Latina: introducción al extremo occidente. México: Siglo XXI.

32. Sáinz, P. \& Calcagno, A. (1999). La economía brasileña ante el Plan Real y su crisis, CEPAL, Santiago de Chile.

33. Van Kleef, P., Ständer, P., Specht, S. \& Hjorth, S. (2012). Global Brazil and the Political Economy of the Brazilian Model. Roskilde: Roskilde University.

34. Villela, A. (2011). A bird's eye view of Brazilian industrialization. En W. Baer y D. Fleischer (Ed). The Economies of Argentina and Brazil. A Comparative Perspective (pp. 38 - 65), Cheltenham: Edward Elgar. 